Pharmacogenomics. 2008 December ; 9(12): 1851-1860. doi:10.2217/14622416.9.12.1851.

\title{
Epigenetics and obesity
}

\author{
Reinhard Stöger \\ Department of Biology, University of Washington, 156 Kincaid Hall, Box 351800, Seattle, WA, 98195 \\ -1800, USA
}

\begin{abstract}
Common DNA sequence variants inadequately explain variability in fat mass among individuals. Abnormal body weights are characteristic of specific imprinted-gene disorders. However, the relevance of imprinted genes to our understanding of obesity among the general population is uncertain. Hitherto unidentified imprinted genes and epigenetic mosaicism are two of the challenges for this emerging field of epigenetics. Subtle epigenetic differences in imprinted genes and gene networks are likely to be present among cells, tissues and individuals. In order to advance obesity research it will be necessary to use genome-wide, next-generation sequencing approaches that allow the detection of such epigenetic differences.
\end{abstract}

\section{Keywords}

chromatin; epigenetic; gene-network; imprinting; methylation; mosaicism; obesity

\section{Genetics of obesity}

Large segments of the world's population are accumulating an abnormally high proportion of body fat. The health risks associated with obesity vary among individuals, but consistently include Type 2 diabetes, hypertension, coronary heart disease and cancer [1-3]. The existing and future impact on public health of these metabolic disorders is immense and as a result, an obese society has been recognized by the pharmaceutical industry as a lucrative market. Major international efforts are underway to explore and document how DNA sequence polymorphisms influence an individual's predisposition to obesity and related syndromes. Such variations in DNA sequence offer hope of a personalized medicine where therapeutics are tailored and matched with patients of a particular genotype [4-8]. Recent advances of wholegenome association studies have led to the identification of common DNA sequence variants associated with obesity and Type 2 diabetes in the general population [9-11]. However, with less than 20 confirmed genomic loci the numbers of alleles known to be associated with obesity are modest and their phenotypic effects minute. Although the hunt for these 'obesity alleles' is not over, it is evident that genetics alone does not provide satisfactory explanations for the rapid global increase in obesity during the last $40-50$ years.

\section{Epigenetics of obesity: a piece of the puzzle}

Epigenetics has gained attention in the past few years as an alternative perspective on the etiology of metabolic disorders [12-19]. Epigenetics is said to describe:

“...the structural adaptation of chromosomal regions so as to register, signal or perpetuate altered activity states." [20] 
While these epigenetic adaptations alter gene activity and are heritable through many cell divisions - even across generations - they do not alter the primary DNA sequence [21]. Molecular mechanisms underlying epigenetic inheritance, such as DNA methylation and chromatin remodeling have been extensively reviewed [22-27].

Rather than providing a comprehensive overview of the current state of epigenetic research in obesity - which soon would be outdated - two related questions and challenges of this new research field are brought into focus in the present review.

\section{- Disregulation of known imprinted genes}

'Genomic imprinting' is a term that describes the inheritance of parent-specific epigenetic information [28,29]. Certain genes acquire either a maternal or paternal imprint during gametogenesis and, as a result imprinted genes are widely expressed from only one allele in the developing embryo and in adult tissues.

Defective genomic imprinting is generally associated with developmental disorders and clinical phenotypes that often include abnormal body weight. It is currently not known whether deregulation of imprinted genes is also a contributing factor to the obesity epidemic in the general population.

\section{- Epigenetic mosaicism}

Epigenetic mosaicism arises when a genomic locus acquires two or more different epigenetic states in cells of one and the same organism. Such mosaicism is a widespread phenomenon documented in many organisms and may account for differences in body weight among people. The challenge now is to identify these epigenetic differences throughout the genome and in many different tissues.

\section{Genomic imprinting: struggle for resources}

The insights gained from studying genomic imprinting have been invaluable in advancing and shaping ideas of the role that epigenetic phenomena play in metabolic disorders. The kinship theory in particular, an attractive hypothesis regarding the evolution of genomic imprinting, is proving to be influential [30-32]. Conflicts regarding resource allocation to individual offspring form the core of this hypothesis [33-35]. The 'interest' of the father is to have big and strong offspring resulting from one particular mating, as this could be the only chance to successfully perpetuate his genes. Therefore, offspring, inherit a genome from the father that is programmed to obtain as many growth-promoting nutrients as possible from the mother, thereby reducing the mother's reproductive fitness. In eutherian mammals, acquisition of maternal resources takes place through placental nutrient uptake during pregnancy, and milk after birth. The mother's 'interest' is, therefore, to partition her resources equally among all of her offspring, which could stem from multiple fathers during her reproductive lifetime. Thus, the kinship theory predicts that the maternally-inherited genome will tend to silence fetal growth-enhancing genes in an attempt to counteract the resource interests of the paternal genome and at the cost of the offspring's fitness [32]. Since mammalian mothers continue to provide nutrients and resources to their offspring for some time after birth, it is thought that the resource conflict can also affect gene expression and phenotype during postnatal stages of life.

\section{Imprinting disorders associated with obesity: examples}

Prader-Willi syndrome (PWS) is the clearest indication yet that epigenetic mechanisms play an essential role in regulating energy balance in humans. Individuals affected by PWS have cognitive impairments and struggle with a voracious and uncontrollable appetite, which is often 
associated with the development of severe obesity within the first 6 years of life. The strong desire for food appears to result from a satiety dysfunction in the CNS [36]. This neurogenetic disorder arises from an imbalanced expression of gene products and transcripts mapping to chromosome 15q11-q13. The genomic region carries parental-specific methylation imprints and in most cases the epigenetic program imprinted on the maternally inherited chromosome cannot compensate for paternal 15q11-q13 deletions, which are the most frequent cause of PWS [37-39].

The GNAS locus - both in mouse and human - provides intriguing support for the kinship theory of genomic imprinting. One of the imprinted mouse genes at this locus encodes the 'extra large' (XL) variant of the guanine nucleotide binding protein G, Gnas Xl, which is involved in signal transduction processes of neuroendocrine tissues [40,41]. Mice deficient of the paternal GnasXl (Gnas $X l^{\text {mat+/pat- }}{ }^{-}$) allele have severely impaired suckling activity, fail to thrive and many animals die during the first 2 days after birth [41]. Surviving Gnas $X l^{\text {mat+/pat- }}$ animals that develop to adulthood stay lean and have decreased fat depots. The elevated metabolic rate of these adult mouse mutants is thought to result from a deregulation in energy balance and sympathetic nerve activity $[41,42]$.

A tissue-specific imprinted gene within the Gnas locus, the G protein $\alpha$-subunit, Gs $\alpha$ is primarily expressed from the maternally inherited allele in renal proximal tubules and in brown and white adipose tissue [43-46]. Tissue-specific expression correlates with allele-specific differences in histone methylation [47].

Pronounced obesity, insulin resistance and hypertrigyceridemia develop when mice inherit a disrupted maternal $G s \alpha,{ }^{\text {mat }-/ p a t+}$ allele $[44,45]$. This metabolic phenotype can be rescued by deletion of a differentially-methylated imprinting control region on the paternal allele. This deletion relieves imprinting and leads to the re-expression of the paternal Gs $\alpha$ allele [42].

Genetic as well as epigenetic abnormalities of the human GNAS locus are also associated with metabolic disorders such as pseudohypopara thyroidism and Albright's hereditary osteodystrophy (AHO) [46-51]. The abnormalities do not entirely parallel the mouse mutant phenotypes, but do have some common features. AHO individuals generally have a short, obese body stature [52].

The above examples illustrate the potential of disregulated genomic imprints to promote functionally opposing effects in energy homeostasis: leanness and obesity, respectively. But the question remains: do the known imprinted genes play a role in the current obesity epidemic?

\section{Subtle imprinting effects in mice influencing body weight}

Results from a recent genome-wide mapping approach suggest that genomic imprinting can influence variation in body composition of adult mice [53]. In their study, Cheverud and colleagues identified imprinted quantitative trait loci ( $i$ QTL) in regions of the mouse genome that previously were not known to be imprinted [53]. Such imprinting effects appear to be quite common, and possibly have not been described earlier because they are relatively small, accounting for only $1-4 \%$ of the phenotypic variance in body composition at each identified locus [53].

Morison and colleagues suggested that numerous imprinted genes with subtle effects remain to be discovered, and that these genes will not map to major, genomic imprinting clusters identified so far in mice and humans [54]. Indeed, estimates of the number of imprinted genes and genomic loci vary greatly [29,54-57]. 
Although parental imprinting occurs in all therian mammals and the molecular mechanism is conserved for many genes, including the IGF2-H19 locus [58], there is discordance among species in the number of imprinted genes [54]. Disparity in litter size between mouse and human is one factor that possibly contributes to the discordance of imprinted genes [59]. Although the mouse is an excellent and tractable model organism in which to study epigenetic deregulation of imprinted genes per se, the discordance between mouse and human in both the number and identities of imprinted genes $[53,57,59]$ limits the utility of mouse for studying the role that deregulated genomic imprinting could play in human obesity.

Based on computer-learning algorithms that recognize certain DNA sequence characteristics such as concentration of repeated elements and recombination hotspots, Luedi and colleagues recently predicted parental imprinting of approximately 150 humans genes [56,57]. For the vast majority of these potentially imprinted genes, differential epigenetic marks have not yet been identified and expression patterns reflecting parent-of-origin specificity await demonstration. Nevertheless, these early findings hint that subtle imprinting effects may also contribute to variation in body mass in humans. Below, that possibility is explored.

\section{Undiscovered parental imprints in humans?}

Genetic and epigenetic abnormalities in regions of the human genome, known to undergo parental imprinting are predominantly associated with distinct developmental and pathological phenotypes [37,60-62]. These phenotypes and their unusual inheritance patterns are often the only evidence of a parental imprint and have, in this way, guided the mapping and identification efforts for many of the currently known imprinted loci in humans. However, there is little evidence that deregulation of these 'clinical-symptoms' imprinting loci is common for individuals affected by the current obesity epidemic. Therefore, it is therefore plausible that other, as yet unidentified imprinted genes, could contribute to subclinical variations in phenotype, including body weight.

A number of genome-wide linkage analyses have been carried out, with the goal of identifying new genomic loci that harbor parent-of-origin effects that influence body weight. Lindsay and colleagues detected regions on maternally-derived chromosomes 5 and 6 , and paternallyderived chromosome 10 with tentative evidence of imprinted genes that might influence the risk of Type 2 diabetes or obesity in Pima Indians [63]. In a follow-up study, it was reported that the birth weight in the Pima population appears to be influenced by loci on the paternallyinherited chromosome 11 [64].

Screening DNA samples from African-American, European-American and German individuals, Price and colleagues found evidence for at least three different obesity-related genetic loci with parental effects [65]. In their genome-wide linkage analysis a paternal effect for BMI was detected for region 13q32, and locations on chromosomes 10p12 and 12q24 suggest a maternal effect on BMI. None of these three loci had been known previously to harbor genomic imprints [65].

The results of two similar genome-wide scans have also provided evidence for the existence of potentially imprinted loci influencing body weight $[66,67]$. Common to all of these studies is the feature that many of the newly mapped loci have not previously been reported as imprinted, and were not detected in the screens performed by other laboratories. With the provision that a parent-of-origin effect does not necessarily provide direct evidence of imprinting [68], these genome-wide studies suggest the existence of many more genomic loci affecting body weight that are perhaps controlled by epigenetic mechanisms. 


\section{Epigenetic mosaicism \& imprinting}

Mackay and colleagues speculate that disturbance of some, as yet unidentified imprinted loci, contribute to transient neonatal diabetes (TND) associated with 6q24 [69], which is a rare imprinting disorder affecting approximately 1:500,000 neonates [62]. The young patients normally require insulin therapy during the first 3 months of life after which remission occurs. Umbilical hernia, macroglossia and learning difficulties are variable but distinct nondiabetic manifestations of the 6q24 disorder. Mosaic hypomethylation at multiple imprinted loci (HIL) was found to be a recurrent, genomic feature in a cohort of individuals that experienced TND and these epigenetic lesions were more prevalent in nonleukocyte cells, such as buccal cells and fibroblasts [69]. Mutations in ZNF57, a gene encoding the zinc finger binding protein 57, have recently been associated with this autosomal, recessive imprinting disorder [70], and the basis for aberrant methylation-mosaicism might be established during early embryogenesis, a developmental stage when ZNF57 is normally expressed [70]. Epigenetic mosaicism among tissues and cells is a phenomenon observed in many species, including humans [71-75]. For instance, epigenetic defects such as loss of imprinting (LOI) of the IGF2 gene is a common event in Wilm's tumor and lung, breast and ovarian cancers and gliomas where the normally silent, maternal allele of this growth-promoting gene is aberrantly activated [76,77]. Altered DNA methylation states are associated with LOI [78].

\section{Epigenetic mosaicism \& detection of subtle epigenetic differences}

The finding that the human genome is likely to contain some as yet unidentified imprinted loci affecting body weight hints that disregulation of imprinting could play a role in the obesity epidemic. Our ability to investigate this possible connection, however, is only as good as our ability to detect epigenetic abnormalities through screening methods typically applied to the general population.

It is possible that subtle imprinting abnormalities - specifically, those that result from epigenetic mosaicism among cells and tissues - have remained undetected in the general population because epigenetic lesions were limited to tissues other than those analyzed. For example, DNA methylation patterns could indicate normal parental imprints during a screen of peripheral blood leukocytes, a common DNA source, while epigenetic defects in white adipose tissue would stay unnoticed. In addition, methods for the detection of DNA methylation, such as methyl-sensitive PCR, may not be adequate for obesity research. Although some of these methods are very sensitive and enable the detection of $0.1 \%$ methylated DNA present in otherwise unmethylated DNA samples [79], they may fail to uncover subtle, but biologically important, methylation differences that can only be detected by sampling many individual DNA molecules derived from a particular genomic locus. For instance, the density of DNA methylation at the human leptin promoter is highly variable among alleles and cells from an individual [80]. While the effect of this mosaicism on gene expression awaits demonstration, it is likely that such methylation differences would go unnoticed by many of the current assays employed to assess epigenetic variations. Thus, tissues to be sampled and techniques to be applied are important factors to be considered for obesity research.

New, massively parallel sequencing methods have great potential, as they allow 'deep sequencing' at genomic loci of interest [81,82]. With these high-throughput methods it will be possible to detect subtle irregularities in DNA methylation patterns among individual DNA molecules, cells and individuals. Similarly, next-generation sequencing technology, in combination with chromatin immunoprecipitation (ChIP-Seq) $[83,84]$, will also provide a detailed picture of the histone modifications in genomic regions that are associated with deregulated energy metabolism. Although this sequencing technology has not yet advanced to the level where an individual's entire genome can be routinely scanned for subtle epigenetic 
differences, the data produced with these new techniques will soon advance our (currently limited) understanding of the epigenetic underpinnings of obesity. Moreover, the use of molecular 'batchstamps' and 'barcodes' will improve the quality of DNA sequence data-sets as they provide a method to validate sequence diversity, and enable researchers to accurately classify valid, contaminant, or redundant sequences $[85,86]$

\section{Environment \& the deregulation of genomic imprinting}

Taken together, there is a good amount of evidence indicating that variation at imprinted loci can influence the body mass of individuals. What could be the cause of these imprinting differences among individuals?

Environmental stimuli and stresses can alter epigenetic modifications and gene expression [78,87-89]. Indeed, abnormal epigenetic patterns at imprinted loci were one of the first indications that external environmental stimuli can influence an individual's epigenome. Manipulation of embryos and embryonic stem cells, routinely employed in assisted reproductive technologies in humans, as well as mammalian cloning and gene-targeting procedures have been found to affect the epigenetic status of imprinted loci $[87,88,90]$. Environmental changes are inevitable during such procedures, insofar as cells and embryos are physically moved and become exposed to unnatural growth conditions. These environmental stresses - occurring during a limited period of time at the earliest stages of development - frequently influence the resulting adult phenotype [91-94]. It has been suggested that an elevated risk of Beckwith-Wiedemann syndrome, a fetal overgrowth and imprinting disorder, results from manipulations that occur during in vitro fertilization [95-98], although donor oocyte quality has not been ruled out as an independent risk factor.

Abnormal birth weights, both low and high, are frequently observed in animals and humans that have experienced early-embryonic interventions [87]. These phenotypic variations are often associated with altered gene expression and changes in DNA methylation patterns at imprinted loci [99-101]. However, the environmental stresses occurring during assisted human reproduction influence only a small fraction $(\sim 3.9 \%)$ of the population born in developed countries [102] and, hence, cannot explain the current obesity epidemic.

Nutrition is an external, environmental signal directly relevant to obesity, and it can affect gene expression at imprinted loci. For example, expression of the imprinted, paternally expressed gene 1 (Pegl/Mest) is markedly elevated in white adipose tissue of genetically identical mice treated with a high-fat diet [103-105]. Similarly, a methyl-deficient diet significantly increases the expression of the imprinted, paternally expressed gene encoding the insulin-like growth factor $2(I g f 2)$ in the prostate of mice and decreases the repressive dimethyl-H3K9 histone modification at this imprinted locus [106]. The Igf 2 locus appears particularly susceptible to external, nutritional signals, as Waterland and colleagues reported that subtle dietary changes during the post-weaning phase of mouse development induces permanent changes in DNA methylation and altered expression at the Igf2 locus [107].

The notion that nutritional interventions can induce DNA methylation changes has garnered considerable interest, both within the research community and with the public [108]. However, considering that much effort has been applied in finding such methylation changes - at imprinted loci in particular - the results to date are rather modest and more results are still anticipated that would demonstrate how nutritionally induced epigenetic alterations affect the expression of specific genes that are directly involved with resource allocation of an organism. 


\section{Environment, mosaicism \& a nonimprinted locus}

Epigenetics, obesity and environment converge at the agouti locus in the mouse genome. This locus is different from those described above, insofar as it does not carry a parental-specific imprint. The agouti gene encodes a signaling molecule that triggers a shift from the production of black eumelanin to yellow pheomelanin in hair follicles. Depending on timing and levels of agouti expression, the coat color of individual mice ranges from yellow to brown (agouti) to black. The coat color is a useful phenotypic marker indicating the activity of the agouti gene and provides a measure of epigenetic mosaicism for this genomic locus in individual animals. Loss-of-function yields mice with black fur that have normal weight [109]. By contrast, ectopic expression of the viable yellow agouti allele $\left(\mathrm{A}^{\mathrm{vy}}\right)$ in heterozygous $\left(\mathrm{A}^{\mathrm{vy} /-}\right)$ animals is associated with yellow fur and a phenotype of obesity and Type 2 diabetes [110]. On the $\mathrm{A}^{\mathrm{vy}}$ allele, agouti transcription is driven by a cryptic promoter present in a retrotransposon that is inserted upstream of the agouti coding region. This transposable element has rendered the activity of the $\mathrm{A}^{\mathrm{vy}}$ allele susceptible to dietary variations during development and the ensuing, pronounced phenotypic variation observed in adult $\mathrm{A}^{\mathrm{vy} /-}$ animals has been correlated with the status of DNA methylation at the retrotransposon: methylation strongly correlates with $\mathrm{A}^{\mathrm{vy}}$ silencing [111-116].

\section{Energy balance: epigenetics of nonimprinted genes \& gene-networks}

The findings at the agouti locus illustrate how nutrition affects the epigenotype and expression of a single gene that does not carry a parental-specific imprint. The question then arises to what extent the genome is modified in its response to environmental signals? Are only a few loci affected, or do diet and other environmental signals induce epigenetic changes in many genes?

Wide-ranging and complex gene networks regulate energy balance $[117,118]$. In human adipose tissue, expression levels of approximately 17,000 genes - more than $70 \%$ of the sampled transcripts - were found to correlate with BMI [119]. Many of the differences in gene expression levels may be established during early postnatal stages of life. Koza and colleagues detected variation in gene expression among 6-week-old, genetically-identical mice that foreshadowed a fourfold difference in fat mass of the same animals in adulthood [120]; the variation in adiposity persisted and could not be altered by dietary changes, which led the authors to suggest that epigenetic mechanisms were in play [120]. These examples suggest that nonimprinted genes may acquire epigenetic states that differ among individuals and promote phenotypic differences, such as variation in adiposity. Indeed, variations in DNA methylation have been detected on the promoters of Leptin, $P P A R \alpha, P E P C K$, a phosphoenolpyruvate carboxykinase and the uncoupling protein $1(U c p 1)$ [80,121,122]. These are nonimprinted genes that play important roles in regulating energy metabolism. It is my opinion that epigenetic variation of non-imprinted genes is the largest contributing factor to fat mass variation among individuals. This assumption is based on a theoretical model, demonstrating that large gene networks evolve to become insensitive to genetic perturbations and allelic sequence variations [123]. The process of this mechanism is termed 'genetic canalization'. I have suggested that the network of genes controlling energy balance of an organism may be buffered against genetic differences, thereby explaining the paucity of known DNA sequence variants that predispose an individual to obesity [124]. Genetic canalization offers a theoretical framework in which to explore alternatives to genetics as a significant contributing factor to the obesity epidemic both in somatic cells and in germ cells. 


\section{Conclusion}

Many laboratories are in the process of exploring how diet and other environmental stimuli influence the epigenome and disease risk. This flurry of ongoing research is set to alter our understanding of obesity and related metabolic disorders.

The extent to which epigenetic mechanisms regulate energy balance - by far surpassing the effects of DNA sequence polymorphisms - will become clear in the coming years. It is likely that new imprinted genes will be identified that promote only subtle phenotypes when expression is deregulated.

The prospect that epigenetic modifications affect expression of a large metabolic gene network consisting of both imprinted and nonimprinted genes, calls for the application of large-scale epigenomic approaches. The challenge is considerable. These genome-wide methods must be very sensitive in order to detect minute epigenetic differences and mosaicisms that in sum may largely define the variation in fat mass among individuals.

\section{Future perspective}

Epigenetics will have a similar trajectory in obesity research to the one that it had in cancer research - it will become a mainstream approach to study disease. However, the timeline will be substantially shorter. Epigenetics emerged from the sidelines to become an integral part of cancer research some 20 years after its emergence as a novel concept in tumor biology. Now that the biological importance and the molecular mechanisms of epigenetic processes are better understood, their roles in the etiology of obesity will be explored without significant reservations and lag time. Rapid advances in the field will be fueled by technical and methodological innovations, based primarily on next-generation sequencing platforms.

The next 5 years will bring identification of genomic loci that carry obesity-specific, epigenetic modifications. This information will be invaluable in the development of diagnostic biomarkers and hence will also be of commercial value. Within the same timeframe, it is conceivable that segments of metabolic gene-networks governed by epigenetic processes will be defined. These epigenetically regulated network modules will emerge as potential drug targets.

Both biotech startups and big pharmaceutical companies are inspired by the prospect that drugs have the potential to alter the epigenome and to reverse disease-related epigenetic abnormalities. Since cancers were the first human pathologies recognized to have a strong epigenetic component, the epigenetic drugs currently available are targeted primarily at these diseases. It is foreseeable that these new epigenetic drugs will be repurposed and that they will find their way into clinical trials designed to test their efficacy in treating obesity and related metabolic disorders. Overall, in the coming years we will see a shift in emphasis from understanding an individual's genetic makeup, towards analyzing a patient's epigenetic profile. This discipline already has a name: 'pharmacoepigenomics' [125]. A variation of computer scientist Alan Kay's remark provides perspective on how the research field of epigenetics and obesity will develop: "the best way to predict the future is to explore it".

\section{Executive summary}

\section{Genetics of obesity}

Genome-wide association studies have identified less than 20 loci for obesity and diabetes - a modest number.

\section{Epigenetics of obesity}


Two emerging questions: the role of genomic imprinting in the obesity epidemic and the extent and detection of epigenetic mosaicism.

\section{Genomic imprinting}

Good evidence exists both in mouse and human, that genomic imprinting evolved as an epigenetic mechanism to regulate and allocate resources.

As yet, unidentified imprinted genes are likely to exist - their expression influences body weight.

\section{Epigenetic mosaicism}

Genes have the potential to acquire two or more different epigenetic states in the same tissue and organism.

Environmental factors contribute to the establishment of epigenetic mosaicism.

\section{Detection of epigenetic mosaicism}

Large-scale, epigenomic approaches based on next-generation sequencing platforms are necessary to identify subtle epigenetic differences.

\section{Energy balance: epigenetics and nonimprinted gene networks}

Large gene networks, composed primarily of nonimprinted genes, regulate energy balance: emerging evidence that these genes are under epigenetic control.

Prediction: epigenetic variation and mosaicism of nonimprinted genes is the largest contributing factor to fat-mass variation among individuals.

\section{Pharmacoepigenomics}

Development of epigenetic biomarkers and application of epigenetic drugs to diagnose and treat obesity.

\section{Acknowledgements}

I am grateful to Lisa Chakrabarti and Diane Genereux for comments on the manuscript, as well as for the reviewers' helpful suggestions.

Financial \& competing interests disclosure

Research by RS is supported by NIH grant GM077464. The author has no other relevant affiliations or financial involvement with any organization or entity with a financial interest in or financial conflict with the subject matter or materials discussed in the manuscript apart from those disclosed.

No writing assistance was utilized in the production of this manuscript.

\section{Bibliography}

Papers of special note have been highlighted as:

- of interest

m of considerable interest

1. Zimmet P. Type 2 (non-insulin-dependent) diabetes - an epidemiological overview. Diabetologia 1982;22:399-411. [PubMed: 7049798]

2. Prentice AM. The emerging epidemic of obesity in developing countries. Int. J. Epidemiol 2006;35:9399. [PubMed: 16326822] 
3. Smyth S, Heron A. Diabetes and obesity: the twin epidemics. Nat. Med 2006;12:75-80. [PubMed: 16397575]

4. Hattersley AT, Pearson ER. Minireview: pharmacogenetics and beyond: the interaction of therapeutic response, $\beta$-cell physiology, and genetics in diabetes. Endocrinology 2006;147:2657-2663. [PubMed: 16556760]

5. Reitman ML, Schadt EE. Pharmacogenetics of metformin response: a step in the path toward personalized medicine. J. Clin. Invest 2007;117:1226-1229. [PubMed: 17476355]

6. Allison M. Is personalized medicine finally arriving? Nat. Biotechnol 2008;26:509-517. [PubMed: 18464779]

7. Lango H, Weedon MN. What will whole genome searches for susceptibility genes for common complex disease offer to clinical practice? J. Intern. Med 2008;263:16-27. [PubMed: 18088250]

8. Vella A, Camilleri M. Pharmacogenetics: potential role in the treatment of diabetes and obesity. Expert Opin. Pharmacother 2008;9:1109-1119. [PubMed: 18422469]

9. Scott LJ, Mohlke KL, Bonnycastle LL, et al. A Genome-wide association study of Type 2 diabetes in Finns detects multiple susceptibility variants. Science 2007;316(5829):1341-1345. [PubMed: 17463248]

10. Saxena R, Voight BF, Lyssenko V, et al. Genome-wide association analysis identifies loci for Type 2 diabetes and triglyceride levels. Science 2007;316:1331-1336. [PubMed: 17463246]

11. Zeggini E, Weedon MN, Lindgren CM, et al. Replication of genome-wide association signals in UK samples reveals risk loci for Type 2 diabetes. Science 2007;316:1336-1341. [PubMed: 17463249]

12. Pembrey ME. Time to take epigenetic inheritance seriously. Eur. J. Hum. Genet 2002;10:669-671. [PubMed: 12404095]

13. Wu G, Bazer FW, Cudd TA, Meininger CJ, Spencer TE. Maternal nutrition and fetal development. J. Nutr 2004;134:2169-2172. [PubMed: 15333699]

14. Simmons R. Developmental origins of adult metabolic disease: concepts and controversies. Trends Endocrinol. Metab 2005;16:390-394. [PubMed: 16118054]

15. Holness MJ, Sugden MC. Epigenetic regulation of metabolism in children born small for gestational age. Curr. Opin. Clin. Nutr. Metab. Care 2006;9:482-488. [PubMed: 16778581]

16. Gallou-Kabani C, Junien C. Nutritional epigenomics of metabolic syndrome: new perspective against the epidemic. Diabetes 2005;54:1899-1906. [PubMed: 15983188]

17. de Moura EG, Passos MC. Neonatal programming of body weight regulation and energetic metabolism. Biosci. Rep 2005;25:251-269. [PubMed: 16283556]

18. Waterland RA. Does nutrition during infancy and early childhood contribute to later obesity via metabolic imprinting of epigenetic gene regulatory mechanisms? Nestle Nutr. Workshop Ser. Pediatr. Program 2005;56:157-171.discussion 171-174

19. Burdge GC, Hanson MA, Slater-Jefferies JL, Lillycrop KA. Epigenetic regulation of transcription: a mechanism for inducing variations in phenotype (fetal programming) by differences in nutrition during early life? Br J. Nutr 2007;97:1036-1046. [PubMed: 17381976]

20. Bird A. Perceptions of epigenetics. Nature 2007;447:396-398. [PubMed: 17522671]

21. Riggs, AD.; Martienssen, RA.; Russo, VEA. Epigenetic mechanisms of gene regulation.. In: Russo, VEA.; Martienssen, RA.; Riggs, AD., editors. Cold Spring Harbor Monograph Series. Vol. 32. Cold Spring Harbor Laboratory Press; New York, USA: 1996. p. 1-4.

22. Bird A. DNA methylation patterns and epigenetic memory. Genes Dev 2002;16:6-21. [PubMed: 11782440]

23. Bernstein BE, Meissner A, Lander ES. The mammalian epigenome. Cell 2007;128:669-681. [PubMed: 17320505]

24. Kouzarides T. Chromatin modifications and their function. Cell 2007;128:693-705. [PubMed: 17320507]

25. Schuettengruber B, Chourrout D, Vervoort M, Leblanc B, Cavalli G. Genome regulation by polycomb and trithorax proteins. Cell 2007;128:735-745. [PubMed: 17320510]

26. Zaratiegui M, Irvine DV, Martienssen RA. Noncoding RNAs and gene silencing. Cell 2007;128:763776. [PubMed: 17320512] 
27. Misteli T. Beyond the sequence: cellular organization of genome function. Cell 2007;128:787-800. [PubMed: 17320514]

28. Reik W, Walter J. Genomic imprinting: parental influence on the genome. Nat. Rev. Genet 2001;2:2132. [PubMed: 11253064]

29. Wood AJ, Oakey RJ. Genomic imprinting in mammals: emerging themes and established theories. PLoS Genet 2006;2:E147. [PubMed: 17121465]

30. Haig D, Westoby M. Parent-specific gene expression and the triploid endosperm. Am. Nat 1989;134:147-155.

31m. Moore T, Haig D. Genomic imprinting in mammalian development: a parental tug-of-war. Trends Genet 1991;7:45-49. [PubMed: 2035190]Highly readable description of the 'kinship' theory of genomic imprinting - a key to understanding how epigenetic mechanisms may regulate energy balance

32. Haig D. The kinship theory of genomic imprinting. Annu. Rev. Ecol. Syst 2000;31:9-32.

33ø. Constancia M, Kelsey G, Reik W. Resourceful imprinting. Nature 2004;432:53-57. [PubMed: 15525980]Thoughtful discussion of genomic imprinting and resource allocation

34. Charalambous M, da Rocha ST, Ferguson-Smith AC. Genomic imprinting, growth control and the allocation of nutritional resources: consequences for postnatal life. Curr. Opin. Endocrinol. Diabetes Obes 2007;14:3-12. [PubMed: 17940412]

35. Frontera M, Dickins B, Plagge A, Kelsey G. Imprinted genes, postnatal adaptations and enduring effects on energy homeostasis. Adv. Exp. Med. Biol 2008;626:41-61. [PubMed: 18372790]

36. Shapira NA, Lessig MC, He AG, James GA, Driscoll DJ, Liu Y. Satiety dysfunction in Prader-Willi syndrome demonstrated by fMRI. J. Neurol. Neurosurg. Psychiatry 2005;76:260-262. [PubMed: 15654046]

37. Nicholls RD, Saitoh S, Horsthemke B. Imprinting in Prader-Willi and Angelman syndromes. Trends Genet 1998;14:194-200. [PubMed: 9613204]

38. Nicholls RD, Knepper JL. Genome organization, function, and imprinting in Prader-Willi and Angelman syndromes. Annu. Rev. Genomics Hum. Genet 2001;2:153-175. [PubMed: 11701647]

39. Horsthemke B, Wagstaff J. Mechanisms of imprinting of the Prader-Willi/Angelman region. Am. J. Med. Genet. A 2008;146A:2041-2052. [PubMed: 18627066]

40. Klemke M, Pasolli HA, Kehlenbach RH, Offermanns S, Schultz G, Huttner WB. Characterization of the extra-large G protein $\alpha$-subunit XL $\alpha$ s. II. Signal transduction properties. J. Biol. Chem 2000;275:33633-33640. [PubMed: 10931851]

41. Plagge A, Gordon E, Dean W, et al. The imprinted signaling protein XL $\alpha$ s is required for postnatal adaptation to feeding. Nat. Genet 2004;36:818-826. [PubMed: 15273686]

42. Xie T, Chen M, Gavrilova O, Lai EW, Liu J, Weinstein LS. Severe obesity and insulin resistance due to deletion of the maternal Gs $\alpha$ allele is reversed by paternal deletion of the Gs $\alpha$ imprint control region. Endocrinology 2008;149:2443-2450. [PubMed: 18202131]

43. Yu S, Yu D, Lee E, et al. Variable and tissue-specific hormone resistance in heterotrimeric Gs protein $\alpha$-subunit $(\mathrm{Gs} \alpha)$ knockout mice is due to tissue-specific imprinting of the gs $\alpha$ gene. Proc. Natl Acad. Sci. USA 1998;95:8715-8720. [PubMed: 9671744]

44. Chen M, Gavrilova O, Liu J, et al. Alternative Gnas gene products have opposite effects on glucose and lipid metabolism. Proc. Natl Acad. Sci. USA 2005;102:7386-7391. [PubMed: 15883378]

45. Germain-Lee EL, Schwindinger W, Crane JL, et al. A mouse model of albright hereditary osteodystrophy generated by targeted disruption of exon 1 of the Gnas gene. Endocrinology 2005;146:4697-4709. [PubMed: 16099856]

46. Plagge A, Kelsey G, Germain-Lee EL. Physiological functions of the imprinted Gnas locus and its protein variants $\mathrm{G} \alpha(\mathrm{s})$ and $\mathrm{XL} \alpha(\mathrm{s})$ in human and mouse. J. Endocrinol 2008;196:193-214. [PubMed: 18252944]

47. Sakamoto A, Liu J, Greene A, Chen M, Weinstein LS. Tissue-specific imprinting of the G protein Gs $\alpha$ is associated with tissue-specific differences in histone methylation. Hum. Mol. Genet 2004;13:819-828. [PubMed: 14976161]

48. Weinstein LS, Gejman PV, Friedman E, et al. Mutations of the Gs $\alpha$-subunit gene in Albright hereditary osteodystrophy detected by denaturing gradient gel electrophoresis. Proc. Natl Acad. Sci. USA 1990;87:8287-8290. [PubMed: 2122458] 
49. Bastepe M, Frohlich LF, Linglart A, et al. Deletion of the NESP55 differentially methylated region causes loss of maternal GNAS imprints and pseudohypoparathyroidism type Ib. Nat. Genet 2005;37:25-27. [PubMed: 15592469]

50. Mariot V, Maupetit-Mehouas S, Sinding C, Kottler ML, Linglart A. A maternal epimutation of GNAS leads to Albright osteodystrophy and parathyroid hormone resistance. J. Clin. Endocrinol. Metab 2008;93:661-665. [PubMed: 18182455]

51. Lalande M. Imprints of disease at GNAS1. J. Clin. Invest 2001;107:793-794. [PubMed: 11285295]

52. Germain-Lee EL. Short stature, obesity, and growth hormone deficiency in pseudohypoparathyroidism Type 1a. Pediatr. Endocrinol. Rev 2006;3(Suppl 2):318-327. [PubMed: 16675931]

53m. Cheverud JM, Hager R, Roseman C, Fawcett G, Wang B, Wolf JB. Genomic imprinting effects on adult body composition in mice. Proc. Natl Acad. Sci. USA 2008;105:4253-4258. [PubMed: $18337500]$ Study describing the existence of novel imprinted loci and their effects on phenotypic variation

54. Morison IM, Ramsay JP, Spencer HG. A census of mammalian imprinting. Trends Genet 2005;21:457-465. [PubMed: 15990197]

55. Barlow DP. Gametic imprinting in mammals. Science 1995;270:1610-1613. [PubMed: 7502071]

56. Luedi PP, Hartemink AJ, Jirtle RL. Genome-wide prediction of imprinted murine genes. Genome Res 2005;15:875-884. [PubMed: 15930497]

57. Luedi PP, Dietrich FS, Weidman JR, Bosko JM, Jirtle RL, Hartemink AJ. Computational and experimental identification of novel human imprinted genes. Genome Res 2007;17:1723-1730. [PubMed: 18055845]

58. Smits G, Mungall AJ, Griffiths-Jones S, et al. Conservation of the H19 noncoding RNA and H19IGF2 imprinting mechanism in therians. Nat. Genet 2008;40(8):971-976. [PubMed: 18587395]

59. Monk D, Arnaud P, Apostolidou S, et al. Limited evolutionary conservation of imprinting in the human placenta. Proc. Natl Acad. Sci. USA 2006;103:6623-6628. [PubMed: 16614068]

60. Lalande M. Parental imprinting and human disease. Annu. Rev. Genet 1996;30:173-195. [PubMed: 8982453]

61. Delaval K, Wagschal A, Feil R. Epigenetic deregulation of imprinting in congenital diseases of aberrant growth. Bioessays 2006;28:453-459. [PubMed: 16615080]

62. Temple IK, Shield JP. Transient neonatal diabetes, a disorder of imprinting. J. Med. Genet 2002;39:872-875. [PubMed: 12471198]

63. Lindsay RS, Kobes S, Knowler WC, Bennett PH, Hanson RL. Genome-wide linkage analysis assessing parent-of-origin effects in the inheritance of Type 2 diabetes and BMI in Pima Indians. Diabetes 2001;50:2850-2857. [PubMed: 11723070]

64. Lindsay RS, Kobes S, Knowler WC, Hanson RL. Genome-wide linkage analysis assessing parentof-origin effects in the inheritance of birth weight. Hum. Genet 2002;110:503-509. [PubMed: 12073022]

65. Dong C, Li WD, Geller F, et al. Possible genomic imprinting of three human obesity-related genetic loci. Am. J. Hum. Genet 2005;76:427-437. [PubMed: 15647995]

66. Gorlova OY, Amos CI, Wang NW, Shete S, Turner ST, Boerwinkle E. Genetic linkage and imprinting effects on body mass index in children and young adults. Eur. J. Hum. Genet 2003;11:425-432. [PubMed: 12774034]

67. Guo YF, Shen H, Liu YJ, et al. Assessment of genetic linkage and parent-of-origin effects on obesity. J. Clin. Endocrinol. Metab 2006;91:4001-4005. [PubMed: 16835282]

68. Hager R, Cheverud JM, Wolf JB. Maternal effects as the cause of parent-of-origin effects that mimic genomic imprinting. Genetics 2008;178:1755-1762. [PubMed: 18245362]

69. Mackay DJ, Boonen SE, Clayton-Smith J, et al. A maternal hypomethylation syndrome presenting as transient neonatal diabetes mellitus. Hum. Genet 2006;120:262-269. [PubMed: 16816970]Study describing mosaic DNA hypomethylation many imprinted loci

70. Mackay DJ, Callaway JL, Marks SM, et al. Hypomethylation of multiple imprinted loci in individuals with transient neonatal diabetes is associated with mutations in ZFP57. Nat. Genet 2008;40:949-951. [PubMed: 18622393] 
71. Monk M. Variation in epigenetic inheritance. Trends Genet 1990;6:110-114. [PubMed: 2132729]

72匹. Rakyan VK, Blewitt ME, Druker R, Preis JI, Whitelaw E. Metastable epialleles in mammals. Trends Genet 2002;18:348-351. [PubMed: 12127774]Insightful discussion of variable expressivity in the absence of genetic heterogeneity

73. Stöger R, Kajimura TM, Brown WT, Laird CD. Epigenetic variation illustrated by DNA methylation patterns of the fragile-X gene FMR1. Hum. Mol. Genet 1997;6:1791-1801. [PubMed: 9302255]

74. Ohlsson R. Loss of IGF2 imprinting: mechanisms and consequences. Novartis Found Symp 2004;262:108-121. [PubMed: 15562825]discussion 121-124, 265-268

75. Fraga MF, Ballestar E, Paz MF, et al. Epigenetic differences arise during the lifetime of monozygotic twins. Proc. Natl Acad. Sci. USA 2005;102:10604-10609. [PubMed: 16009939]

76. Rainier S, Johnson LA, Dobry CJ, Ping AJ, Grundy PE, Feinberg AP. Relaxation of imprinted genes in human cancer. Nature 1993;362:747-749. [PubMed: 8385745]

77. Ogawa O, Eccles MR, Szeto J, et al. Relaxation of insulin-like growth factor II gene imprinting implicated in Wilms' tumour. Nature 1993;362:749-751. [PubMed: 8097018]

78. Feinberg AP. Phenotypic plasticity and the epigenetics of human disease. Nature 2007;447:433-440. [PubMed: 17522677]

79. Herman JG, Graff JR, Myohanen S, Nelkin BD, Baylin SB. Methylation-specific PCR: a novel PCR assay for methylation status of CpG islands. Proc. Natl Acad. Sci. USA 1996;93:9821-9826. [PubMed: 8790415]

80匹. Stöger R. In vivo methylation patterns of the Leptin promoter in human and mouse. Epigenetics 2006;1:155-162. [PubMed: 17965621]Example of extensive DNA methylation mosaicism around a metabolically important gene

81. Appasani K. Epigenomics and sequencing: an intertwined and emerging big science of the next decade. Pharmacogenomics 2007;8:1109-1113. [PubMed: 17924826]

82. Schuster SC. Next-generation sequencing transforms today's biology. Nat. Methods 2008;5:16-18. [PubMed: 18165802]

83. Mardis ER. ChIP-seq: welcome to the new frontier. Nat. Methods 2007;4:613-614. [PubMed: 17664943]

84. Mikkelsen TS, Ku M, Jaffe DB, et al. Genome-wide maps of chromatin state in pluripotent and lineage-committed cells. Nature 2007;448:553-560. [PubMed: 17603471]

85. Miner BE, Stöger R, Burden AF, Laird CD, Hansen RS. Molecular barcodes detect redundancy and contamination in hairpin-bisulfite PCR. Nucleic Acids Res 2004;32:E135. [PubMed: 15459281]

86. McCloskey ML, Stöger R, Hansen RS, Laird CD. Encoding PCR products with batch-stamps and barcodes. Biochem. Genet 2007;45:761-767. [PubMed: 17955361]

87. Thompson SL, Konfortova G, Gregory RI, Reik W, Dean W, Feil R. Environmental effects on genomic imprinting in mammals. Toxicol. Lett 2001;120:143-150. [PubMed: 11323171]

88. Jaenisch R, Bird A. Epigenetic regulation of gene expression: how the genome integrates intrinsic and environmental signals. Nat. Genet 2003;(Suppl 33):245-254. [PubMed: 12610534]

89. Jirtle RL, Skinner MK. Environmental epigenomics and disease susceptibility. Nat. Rev. Genet 2007;8:253-262. [PubMed: 17363974]

90. Arnaud P, Feil R. Epigenetic deregulation of genomic imprinting in human disorders and following assisted reproduction. Birth Defects Res. C. Embryo Today 2005;75:81-97. [PubMed: 16035043]

91. Young LE, Sinclair KD, Wilmut I. Large offspring syndrome in cattle and sheep. Rev. Reprod 1998;3:155-163. [PubMed: 9829550]

92. Doherty AS, Mann MR, Tremblay KD, Bartolomei MS, Schultz RM. Differential effects of culture on imprinted H19 expression in the preimplantation mouse embryo. Biol. Reprod 2000;62:15261535. [PubMed: 10819752]

93. Khosla S, Dean W, Brown D, Reik W, Feil R. Culture of preimplantation mouse embryos affects fetal development and the expression of imprinted genes. Biol. Reprod 2001;64:918-926. [PubMed: 11207209]

94. Sinclair KD, Young LE, Wilmut I, McEvoy TG. In-utero overgrowth in ruminants following embryo culture: lessons from mice and a warning to men. Hum. Reprod 2000;15(Suppl 5):68-86. [PubMed: 11263539] 
95. DeBaun MR, Niemitz EL, Feinberg AP. Association of in vitro fertilization with BeckwithWiedemann syndrome and epigenetic alterations of LIT1 and H19. Am. J. Hum. Genet 2003;72:156160. [PubMed: 12439823]

96. Gicquel C, Gaston V, Mandelbaum J, Siffroi JP, Flahault A, Le Bouc Y. In vitro fertilization may increase the risk of Beckwith-Wiedemann syndrome related to the abnormal imprinting of the KCN1OT gene. Am. J. Hum. Genet 2003;72:1338-1341. [PubMed: 12772698]

97. Maher ER, Brueton LA, Bowdin SC, et al. Beckwith-Wiedemann syndrome and assisted reproduction technology (ART). J. Med. Genet 2003;40:62-64. [PubMed: 12525545]

98. Halliday J, Oke K, Breheny S, Algar E, J Amor D. Beckwith-Wiedemann syndrome and IVF: a casecontrol study. Am. J. Hum. Genet 2004;75:526-528. [PubMed: 15284956]

99. Dean W, Bowden L, Aitchison A, et al. Altered imprinted gene methylation and expression in completely ES cell-derived mouse fetuses: association with aberrant phenotypes. Development 1998;125:2273-2282. [PubMed: 9584126]

100. Mann MR, Lee SS, Doherty AS, et al. Selective loss of imprinting in the placenta following preimplantation development in culture. Development 2004;131:3727-3735. [PubMed: 15240554]

101. Rivera RM, Stein P, Weaver JR, Mager J, Schultz RM, Bartolomei MS. Manipulations of mouse embryos prior to implantation result in aberrant expression of imprinted genes on day 9.5 of development. Hum. Mol. Genet 2008;17:1-14. [PubMed: 17901045]

102. Andersen AN, Goossens V, Gianaroli L, Felberbaum R, de Mouzon J, Nygren KG. Assisted reproductive technology in Europe, 2003. Results generated from European registers by ESHRE. Hum. Reprod 2007;22:1513-1525. [PubMed: 17470881]

103. Takahashi M, Kamei Y, Ezaki O. Mest/Peg1 imprinted gene enlarges adipocytes and is a marker of adipocyte size. Am. J. Physiol. Endocrinol. Metab 2005;288:E117-E124. [PubMed: 15353408]

104. Kamei Y, Suganami T, Kohda T, et al. Peg1/Mest in obese adipose tissue is expressed from the paternal allele in an isoform-specific manner. FEBS Lett 2007;581:91-96. [PubMed: 17182038]

105. Nikonova L, Koza RA, Mendoza T, Chao PM, Curley JP, Kozak LP. Mesoderm-specific transcript is associated with fat mass expansion in response to a positive energy balance. FASEB J 2008;22 (11):3925-3937. [PubMed: 18644838]

106. Dobosy JR, Fu VX, Desotelle JA, et al. A methyl-deficient diet modifies histone methylation and alters Igf2 and H19 repression in the prostate. Prostate 2008;68:1187-1195. [PubMed: 18459101]

107. Waterland RA, Lin JR, Smith CA, Jirtle RL. Post-weaning diet affects genomic imprinting at the insulin-like growth factor 2 (Igf2) locus. Hum. Mol. Genet 2006;15:705-716. [PubMed: 16421170]

108. Blakeslee S. A pregnant mother's diet may turn the genes around. The New York Times, NY, USA. October;2003

109. Duhl DM, Vrieling H, Miller KA, Wolff GL, Barsh GS. Neomorphic agouti mutations in obese yellow mice. Nat. Genet 1994;8:59-65. [PubMed: 7987393]

110. Perry WL, Copeland NG, Jenkins NA. The molecular basis for dominant yellow agouti coat color mutations. Bioessays 1994;16:705-707. [PubMed: 7980472]

111. Wolff GL, Kodell RL, Moore SR, Cooney CA. Maternal epigenetics and methyl supplements affect agouti gene expression in Avy/a mice. FASEB J 1998;12:949-957. [PubMed: 9707167]Landmark study establishing a link between diet and epigenetic gene regulation

112. Morgan HD, Sutherland HG, Martin DI, Whitelaw E. Epigenetic inheritance at the agouti locus in the mouse. Nat. Genet 1999;23:314-318. [PubMed: 10545949]

113. Cooney CA, Dave AA, Wolff GL. Maternal methyl supplements in mice affect epigenetic variation and DNA methylation of offspring. J. Nutr 2002;132:S2393-S2400.

114. Waterland RA, Jirtle RL. Transposable elements: targets for early nutritional effects on epigenetic gene regulation. Mol. Cell Biol 2003;23:5293-5300. [PubMed: 12861015]

115. Cropley JE, Suter CM, Beckman KB, Martin DI. Germ-line epigenetic modification of the murine $\mathrm{A}^{\mathrm{vy}}$ allele by nutritional supplementation. Proc. Natl Acad. Sci. USA 2006;103:17308-17312. [PubMed: 17101998]

116. Dolinoy DC, Weidman JR, Waterland RA, Jirtle RL. Maternal genistein alters coat color and protects $\mathrm{A}^{\mathrm{vy}}$ mouse offspring from obesity by modifying the fetal epigenome. Environ. Health Perspect 2006;114:567-572. [PubMed: 16581547] 
117. Jeong H, Tombor B, Albert R, Oltvai ZN, Barabasi AL. The large-scale organization of metabolic networks. Nature 2000;407:651-654. [PubMed: 11034217]

118. Wagner A. The large-scale structure of metabolic networks: a glimpse at life's origin. Complexity 2002;8:15-19.

119. Chen Y, Zhu J, Lum PY, et al. Variations in DNA elucidate molecular networks that cause disease. Nature 2008;452:429-435. [PubMed: 18344982]

120匹. Koza RA, Nikonova L, Hogan J, et al. Changes in gene expression foreshadow diet-induced obesity in genetically identical mice. PLoS Genet 2006;2:E81. [PubMed: 16733553]Demonstrating a link between diet-induced obesity and epigenetic mechanisms

121. Burdge GC, Slater-Jefferies J, Torrens C, Phillips ES, Hanson MA, Lillycrop KA. Dietary protein restriction of pregnant rats in the F0 generation induces altered methylation of hepatic gene promoters in the adult male offspring in the F1 and F2 generations. Br J. Nutr 2007;97:435-439. [PubMed: 17313703]

122. Kiskinis E, Hallberg M, Christian M, et al. RIP140 directs histone and DNA methylation to silence Ucp1 expression in white adipocytes. EMBO J 2007;26:4831-4840. [PubMed: 17972916]

123. Siegal ML, Bergman A. Waddington's canalization revisited: developmental stability and evolution. Proc. Natl Acad. Sci. USA 2002;99:10528-10532. [PubMed: 12082173]

124. Stöger R. The thrifty epigenotype: an acquired and heritable predisposition for obesity and diabetes? Bioessays 2008;30:156-166. [PubMed: 18197594]

125. Szyf M. Toward a discipline of pharmacoepigenomics. Curr. Pharmacogenomics 2004;2:357-377. 